\title{
PARARHINEBOTHROIDES HOBERGI N. GEN. N. SP. (EUCESTODA: TETRAPHYLLIDEA) IN UROBATIS TUMBESENSIS (CHONDRICHTHYES: MYLIOBATIFORMES) FROM COASTAL ECUADOR
}

\author{
David Zamparo, Daniel R. Brooks*, and Ramiro Barriga† \\ Centre for Comparative Biology \& Biodiversity, Department of Zoology, University of Toronto, Toronto, Ontario M5S 3G5, Canada
}

\begin{abstract}
A new species of tetraphyllidean eucestode inhabiting Urobatis tumbesensis from inshore waters of southeastern Ecuador shares 3 synapomorphies with Rhinebothroides spp.: apical bothridial suckers poorly differentiated from the marginal loculi, internal seminal vesicles, and insertion of the vas deferens dorsally closer to the poral than the aporal end of the cirrus sac. The new species differs from Rhinebothroides spp. by lacking medial bothridial septa and loculi and having symmetrical ovarian arms, and possesses an apparent autapomorphic trait by having the vas deferens tapering to a narrow tube before entering the cirrus sac, extending posteriorly to the posterior end of the cirrus sac where it expands into an external seminal vesicle running ventral to the cirrus sac anteriorly to anterior to the vagina. In Rhinebothroides spp., the vas deferens is expanded into an external seminal vesicle near the insertion into the cirrus sac As the sister group of Rhinebothroides, we propose a new genus to accommodate the new species. Phylogenetic evaluation of phyllobothriids recently assigned to Anthocephalum shows that they represent a paraphyletic assemblage of species of varying degrees of relatedness to Rhinebothroides spp. and the new species. Uncovering the relationships of the new species and the various species assigned to Anthocephalum permitted reevaluation of character transformations used in previous phylogenetic analysis of Rhinebothroides. Transformation series for 3 characters, previously based on functional outgroup comparisons, changed and a new character, length of cirrus sac, was added. The new phylogenetic analysis differs from the previous hypothesis only in placing $R$. scorzai as the sister species of $R$. circularisi $+R$. venezuelae $+R$. moralarai rather than of $R$. freitasi $+R$. glandularis $+R$. mclennanae. The occurrence of the sister species of Rhinebothroides in a Pacific Ocean stingray adds additional support to the hypothesis of Pacific origins of South American freshwater stingrays.
\end{abstract}

Among the helminths known to inhabit the Neotropical freshwater stingrays are members of 2 genera of tetraphyllidean eucestodes, Potamotrygonocestus Brooks and Thorson, 1976, and Rhinebothroides Mayes, Brooks, and Thorson, 1981, that are restricted to potamotrygonids. Brooks, Thorson, and Mayes (1981) first proposed, based on phylogenetic analysis of the parasites of potamotrygonids, that the marine ancestor of the freshwater stingrays entered freshwater habitats from the Pacific Ocean before the uplifting of the Andes. Subsequent studies (e.g., information summarized in Brooks and McLennan [1993] and in Hoberg et al. [1998]) have identified putative sister groups for 2 lineages of Acanthobothrium van Beneden, 1850, for Rhinebothrium Linton, 1890, for Eutetrarhynchus Pintner, 1913, and for Echinocephalus Molin, 1858, occurring in coastal marine stingrays in the Pacific. In this report, we describe a new species based on specimens collected in the Pacific inshore marine stingray Urobatis tumbesensis (McEachren and Chirichigno) from Ecuador, and provide evidence that it represents the marine sister species of Rhinebothroides.

\section{MATERIALS AND METHODS}

Stingrays were caught by local fishermen at night with long lines or in gill nets, and examined early the following morning. Cestodes were removed from the spiral valve, placed in dilute saline, then fixed with hot alcohol-formaldehyde-acetic fixative (AFA) and stored in 70\% ethanol. Whole mounts were stained with Mayer's hematoxylin and mounted in Canada balsam. Measurements, in micrometers unless otherwise stated, are given as ranges with mean value followed by sample size in parentheses. All figures were drawn with the aid of a drawing tube.

Phylogenetic analysis was performed following the protocols of phylogenetic systematics (Wiley et al., 1991). Analysis of the species of Rhinebothroides was implemented using the PAUP computer program version 3.1.1 (Swofford, 1993). Characters were polarized using out-

Received 6 August 1998; revised 13 November 1998; accepted 13 November 1998

* To whom correspondence should be addressed.

† Escuela Politecnica Nacional, Quito, Ecuador. group comparisons; all transformation series were run unordered, and the total data set was analyzed using the Branch and Bound algorithm.

\section{DESCRIPTION}

Pararhinebothroides n. gen.

Diagnosis: Eucestoda, Tetraphyllidea, Phyllobothriidae. Scolex with 4 pedunculated bothridia, each with row of marginal loculi; medial loculi lacking. Strobila apolytic. Genital pores lateral, alternating irregularly. Testes numerous, anterior to cirrus sac. Cirrus sac with armed cirrus and internal seminal vesicle. Vas deferens joining cirrus sac at anterior margin of cirrus sac, more porally than aporally; expanded to form saccate external seminal vesicle. Ovary near posterior end of proglottid, X-shaped in cross section; arms symmetrical. Vagina anterior to cirrus sac. Vitelline follicles lateral. Uterus saccate, lacking lateral diverticula. Parasites in spiral valves of marine stingrays. Type species as follows.

\section{Pararhinebothroides hobergi n. sp. (Figs. 1-3)}

Description (based on 23 specimens): Stobila acraspedote, apolytic, up to $28 \mathrm{~mm}$ long, composed of 53-98 proglottids. Scolex $0.86-1.27$ $\mathrm{mm}(\bar{x}=1.06, \mathrm{n}=15)$ wide, with 4 pedicellated, bilobed, laterally elongate unarmed bothridia lacking muscular rim; apical complex lacking. Pedicels $150-250$ long, $(\bar{x}=207, \mathrm{n}=15)$ long. Bothridia 250$450(\bar{x}=378, \mathrm{n}=15)$ long, 500-850 ( $\bar{x}=692, \mathrm{n}=15)$ wide, with more than 100 weakly developed marginal loculi; apical accessory sucker lacking. Neck $225-300$ long. Mature proglottids $685-1,830(\bar{x}$ $=1,372, \mathrm{n}=21)$ long, $188-325(\bar{x}=268, \mathrm{n}=21)$ wide. Gravid, detached, proglottids $1.63-2.58 \mathrm{~mm}(\bar{x}=1.98, \mathrm{n}=9)$ long, $255-330$ $(\bar{x}=291, \mathrm{n}=9)$ wide; maximum width occurring at level of genital pore, posterior end tapered. Testes in 2 fields in anterior $2 / 3$ of proglottid, 33-44 in number $(\bar{x}=39, \mathrm{n}=21) ; 15-22$ aporal $(\bar{x}=19, \mathrm{n}=21)$, $17-24$ poral $(\bar{x}=20, \mathrm{n}=21) ; 49-77$ in diameter $(\bar{x}=62, \mathrm{n}=94)$. Testes lacking or reduced in size, number in gravid proglottids. Cirrus sac elongate, curving posteriorly to between anterior arms of ovarian lobes; $140-300$ long $(\bar{x}=185, \mathrm{n}=21), 55-180$ wide $(\bar{x}=93, \mathrm{n}=$ $21)$ in mature proglottids, $183-250(\bar{x}=202, \mathrm{n}=8)$ long, $100-135(\bar{x}$ $=116, \mathrm{n}=8$ ) wide in gravid proglottids, containing spined eversible cirrus, internal seminal vesicle. Vas deferens entering cirrus sac anteriorly, porally, extending posteriorly to near ovarian isthmus, expanding as proglottid develops into saclike external seminal vesicle extending anteriorly and ventrally across cirrus sac, joining coiled vas deferens 


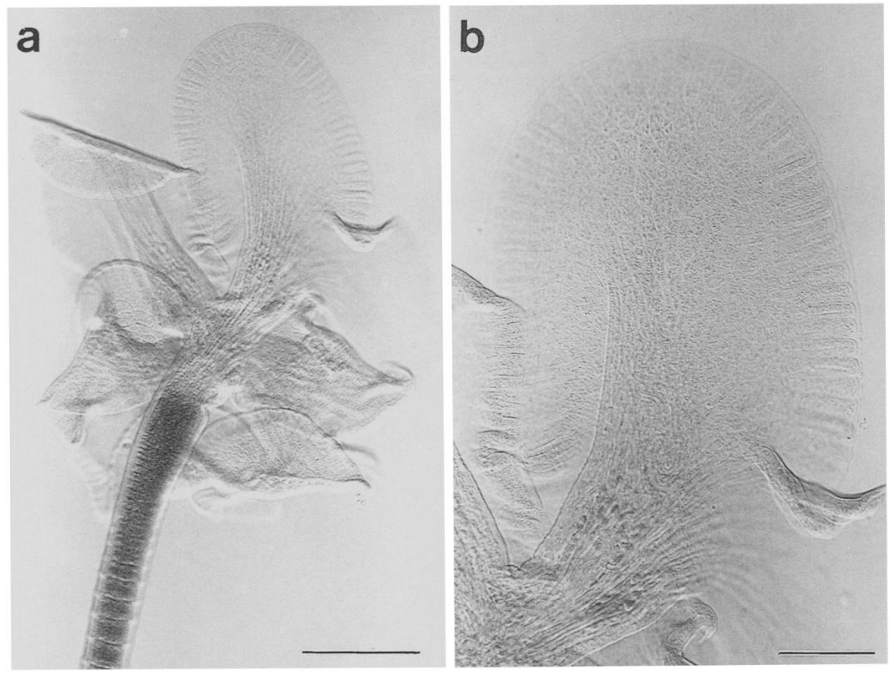

FIGURE 1. Pararhinebothroides hobergi n. gen. n. sp. a. Photomicrograph of scolex. Scale bar $=250 \mu \mathrm{m}$. b. Photomicrograph of bothridium, showing marginal loculi. Scale bar $=100 \mu \mathrm{m}$.

anterior to vagina. Genital pores alternating irregularly, located 66-79\% $(\bar{x}=74 \%, \mathrm{n}=21)$ of proglottid length from anterior end in mature proglottids, $64-72 \%(\bar{x}=69 \%, \mathrm{n}=9)$ of proglottid length from anterior end in gravid proglottids. Vagina anterior to cirrus sac, curving posteriorly around aporal side of cirrus sac, becoming coiled; vaginal sphincter present. Ovaries $\mathrm{H}$-shaped, bilobed with symmetrical lobes in frontal view, $\mathrm{X}$-shaped in cross section; extending from immediately posterior to level of genital pore to near posterior end of proglottid; 125-490 $(\bar{x}$ $=246, \mathrm{n}=21)$ long, $113-225$ wide at isthmus $(\bar{x}=180, \mathrm{n}=21)$ in mature proglottids, 375-660 ( $\bar{x}=496, \mathrm{n}=9)$ long, 175-250 ( $\bar{x}=209$, $\mathrm{n}=9$ ) wide at isthmus in gravid proglottids. Vitelline follicles lateral, 23-45 $(\bar{x}=32, \mathrm{n}=74)$ in diameter in mature proglottids, 49-75 $(\bar{x}=$ $66, \mathrm{n}=37)$ in gravid proglottids, extending nearly entire length of proglottid, interrupted porally around genital pore and ovary in late mature proglottids. Uterus in gravid proglottids medial, extending preporally to near anterior end of proglottid, lacking diverticula.

\section{Taxonomic summary}

Host: Urobatis tumbesensis (McEachren and Chirichigno) (Chondrichthyes: Myliobatiformes: Urotyrgonidae).

Site of infection: Spiral valve.

Locality: Vicinity of Puerto Hualtaco, Provincia del Oro, Ecuador.

Specimens deposited: Holotype: MEPN 25455. Paratypes: MEPN 25456; USNPC 88544.

Etymology: This species is named for Eric P. Hoberg, U.S. National Parasite Collection, in recognition of his unparalleled contributions to eucestode systematics.

\section{Remarks}

Mayes et al. (1981) suggested that certain species assigned at that time to Phyllobothrium van Beneden, 1850 , particularly P. centrurum Southwell, 1925, and P. kingae Schmidt, 1978, resembled species of Rhinebothroides Mayes, Brooks, and Thorson, 1981 by having bothridia lacking muscular rims ringed by marginal loculi. Brooks, Mayes, and Thorson (1981a) considered this trait a synapomorphy linking those species into a clade of unspecified membership and taxonomic category, because they were interested only in assessing the phylogenetic relationships of Rhinebothroides spp. Brooks and Amato (1992) used the same members of Phyllobothrium as outgroups in assessing the sistergroup relationships of Rhinebothroides mclennanae Brooks and Amato, 1992, to other members of the genus. In an effort to subdivide the unwieldy and presumably paraphyletic Phyllobothrium, Ruhnke (1994) resurrected Anthocephalum Linton, 1890, for A. gracile and 4 other species that he considered to form a phenetically coherent assemblage. He included $P$. centrurum but not $P$. kingae in his conception of An-
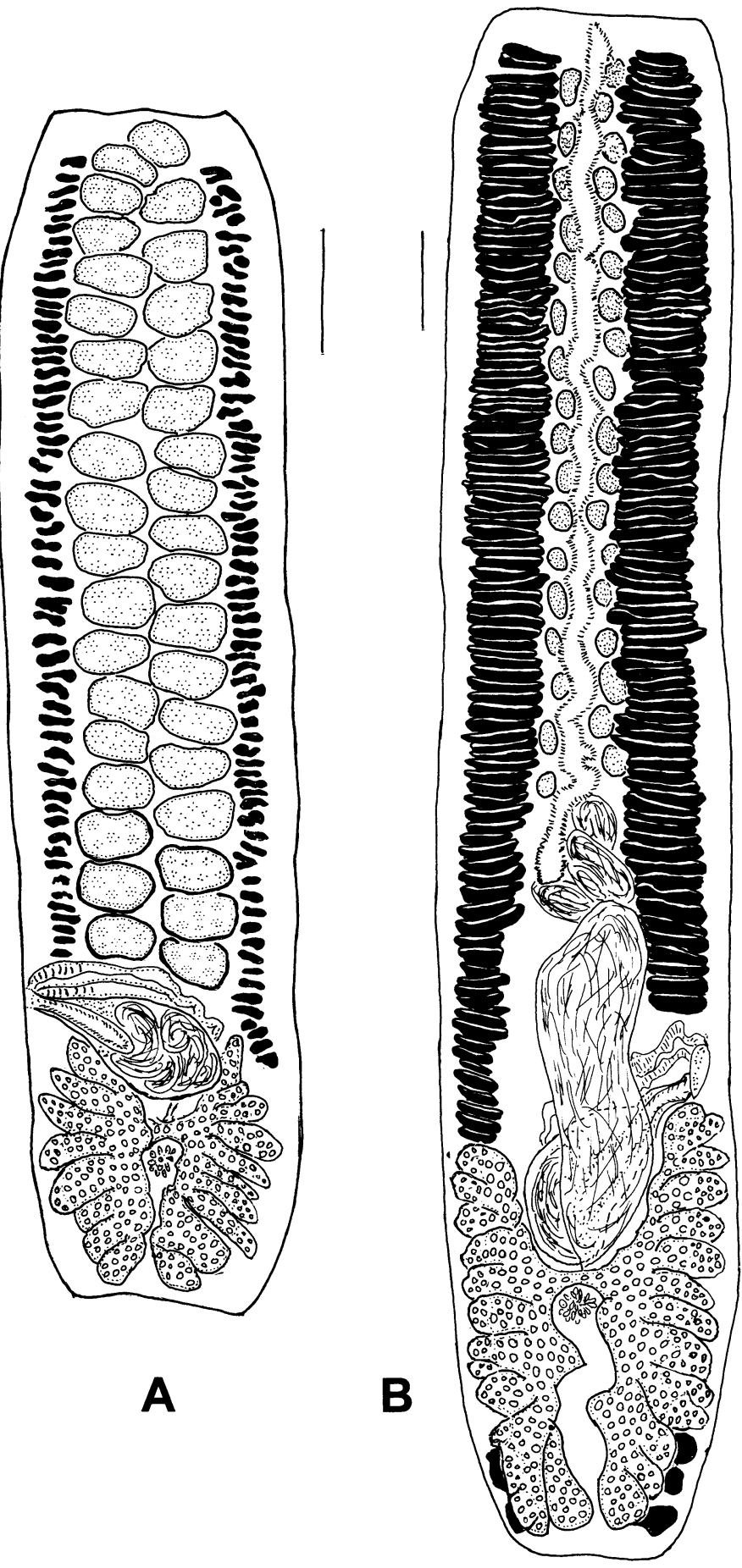

FIGURE 2. Pararhinebothroides hobergi n. gen. n. sp. a. Early mature proglottid. b. Late mature proglottid showing lateral ovarian expansion and uterine development. Scale bars $=200 \mu \mathrm{m}$.

thocephalum, although he considered $P$. kingae something called a "covert member" of the genus. Ruhnke did not mention the studies (Brooks, Mayes, and Thorson, 1981; Mayes et al., 1981; Brooks and Amato, 1992) first suggesting that $P$. centrurum and $P$. kingae might be more closely related to each other than to other members of Phyllobothrium, nor did he mention the possibility that Rhinebothroides spp. might be closely related to $P$. centrurum and relatives. The new species described herein provides additional evidence pertaining to this issue. The following phylogenetic analysis (summarized in Fig. 4) provides a 


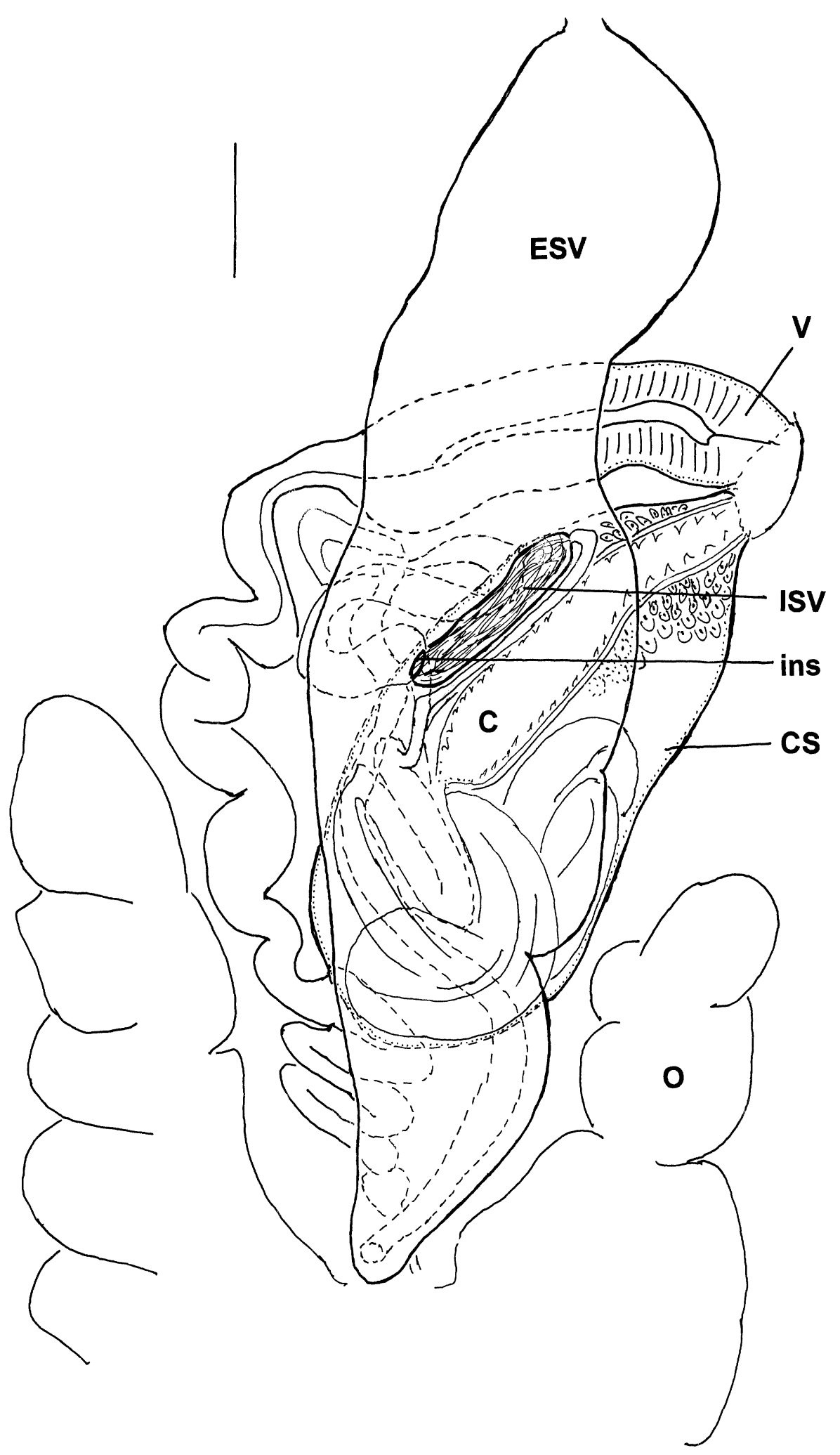

FIGURE 3. Pararhinebothroides hobergi $\mathrm{n}$. gen. $\mathrm{n}$. sp. Terminal genitalia, ventral view. $\mathrm{C}=$ cirrus; $\mathrm{CS}=$ cirrus sca; ESV $=$ external seminal vesicle; Ins $=$ insertion of vas deferens; ISV $=$ internal seminal vesicle; $\mathrm{O}=$ ovary; $\mathrm{V}=$ vagina. Scale bar $=50 \mu \mathrm{m}$. 


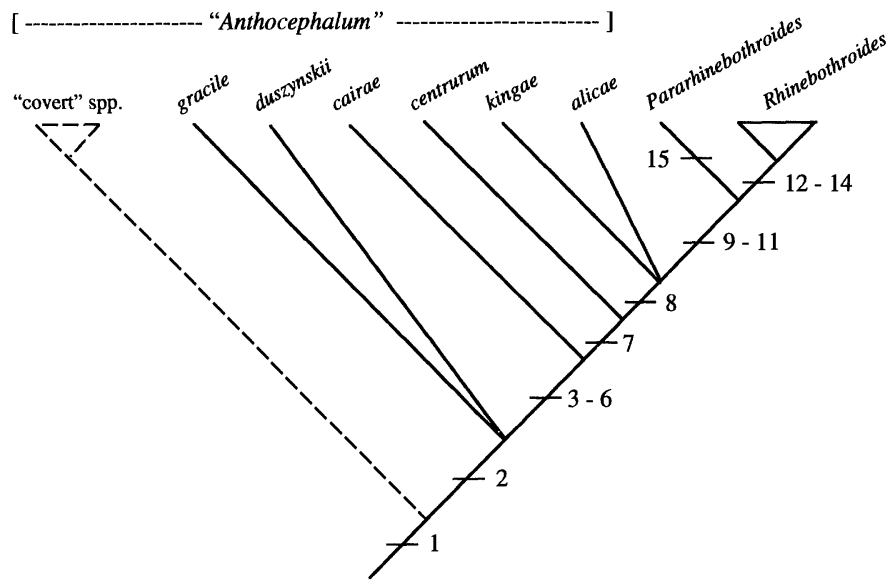

FIGURE 4. Phylogenetic tree for Pararhinebothroides, Rhinebothroides, and close relatives. Numbers accompanying slash marks on various branches represent the following synapomorphies: (1) unarmed bothridia lacking muscular rims and possessing marginal loculi; (2) genital pores in the posterior $1 / 4$ of the proglottid, immediately anterior to the anterior arms of the ovary; (3) fewer than 100 testes per proglottid; (4) cirrus sacs curved posteriorly and extending posteriorly to between the anterior ovarian lobes; (5) vitelline follicles interrupted by the cirrus sac and ovary in fully mature proglottids; (6) coiled vaginae; (7) testes arranged in only a single layer; (8) testes arranged in only 2 longitudinal columns in frontal view; (9) apical accessory bothridial suckers poorly differentiated from the marginal bothridial loculi; (10) internal seminal vesicles; (11) insertion of the external seminal vesicle/vas deferens dorsally closer to the poral end of the cirrus sac than to the aporal end; (12) medial bothridial loculi in addition to the marginal ones; (13) aporal ovarian lobes extending anterior to the level of the genital pore; (14) uteri with lateral diverticula; (15) vas deferens extending posterior to the cirrus sac before expanding into a saclike external seminal vesicle that runs ventral to the cirrus sac anterior to the vagina. Note that the species placed by Ruhnke (1994) in Anthocephalum are paraphyletic. The species Ruhnke (1994) termed "covert members" of Anthocephalum are included at the base of the tree with a dotted line indicating our lack of information about their precise relationships to each other and to the other species considered in the analysis.

context general enough to test the monophyly of Ruhnke's conception of Anthocephalum and to provide phylogenetic support for our decision to propose a separate genus for the new species described herein.

By having unarmed bothridia lacking muscular rims and possessing marginal loculi (character 1 in Fig. 4), the new species resembles members of Rhinebothroides Mayes, Brooks, and Thorson, 1981, and the species commonly placed in the paraphyletic Phyllobothrium that were also included as assigned and as "covert" members of Anthocephalum by Ruhnke (1994). Within that assemblage, the 5 species assigned by Ruhnke (1994) directly to Anthocephalum Linton, 1890 (i.e., the assigned members of the genus), Phyllobothrium kingae Schmidt, 1978 Rhinebothroides spp., and the new species exhibit the synapomorphy of having genital pores in the posterior $1 / 4$ of the proglottid, immediately anterior to the anterior arms of the ovary (character 2 in Fig. 4). Within this clade, 3 of the 5 species assigned by Ruhnke (1994) to Anthocephalum (A. centrurum, A. alicae, and A. cairae), Phyllobothrium kingae Schmidt, 1978, Rhinebothroides spp., and the new species exhibit 4 additional synapomorphies: fewer than 100 testes per proglottid, cirrus sacs curved posteriorly and extending posteriorly to between the anterior ovarian lobes, vitelline follicles interrupted around the cirrus sac and ovary, and coiled vaginae (characters 3-6 in Fig. 4). Ruhnke (1994) reported that $A$. duszynskii had 35-71 testes per proglottid in the ventralmost or dorsalmost field, but also noted that testes occurred in several layers. Therefore, it is likely that $A$. duszynskii actually has more than 100 testes per proglottid when all testes are taken into account, as is usually done for species in which the testes occur in multiple layers (e.g., Brooks, Mayes, and Thorson, 1981b; Campbell and Williams, 1984; Hoberg et al., 1991; Toth et al., 1992; Hoberg and Measures,
1995; Brooks and Barriga, 1995; Hoberg et al., 1995). Accordingly, we place $A$. duszynskii in a trichotomy with A. gracile in Figure 4. Anthocephalum centrurum, A. alicae, Phyllobothrium kingae Schmidt, 1978, Rhinebothroides spp., and the new species exhibit the synapomorphy of having testes arranged in only a single layer in cross section (easily confirmed in whole mounts as well) (character 7 in Fig. 4). Anthocephalum alicae, Phyllobothrium kingae Schmidt, 1978, Rhinebothroides spp., and the new species exhibit the synapomorphy of having testes arranged in only 2 longitudinal columns in frontal view (character 8 in Fig. 4). The new species shares 3 synapomorphies with Rhinebothroides spp.: apical accessory bothridial suckers poorly, if at all, differentiated from the marginal bothridial loculi; internal seminal vesicles; and insertion of the external seminal vesicle/vas deferens dorsally closer to the poral end of the cirrus sac than to the aporal end (characters 9-11 in Fig. 4). Rhinebothroides spp. differ from the new species by having 3 autapomorphies for the genus: medial bothridial loculi in addition to the marginal ones; aporal ovarian lobes extending anterior to the level of the genital pore (this anterior expansion of the maturing ovary contrasts with the lateral expansion in the other species under discussion, probably explaining the persistence of vitelline follicles along the margins of the ovary in Rhinebothroides spp.); and uteri with lateral diverticula (characters 12-14 in Fig. 4). The new species and Rhinebothroides spp. exhibit an additional difference: in Rhinebothroides spp. the vas deferens is expanded to form a saclike external seminal vesicle very close to the cirrus sac, whereas in the new species the vas deferens extends posterior to the cirrus sac before also expanding into a saclike external seminal vesicle that runs ventral to the cirrus sac anterior to the vagina (Fig. 3). The condition in Rhinebothroides spp. is similar to that found in other tetraphyllideans, with the exception that the expansion of the vas deferens to form an external seminal vesicle is much more pronounced than in other known species. The condition exhibited by the new species seems to be autapomorphic for it (character 15 in Fig. 4). Figure 4 summarizes the distribution of apomorphic traits discussed above in the form of a phylogenetic tree, depicting the new species as the sister species of Rhinebothroides. Based on that sistergroup relationship, and the putative occurrence of an autapomorphy for the new species, we propose Pararhinebothroides $\mathrm{n}$. gen. for it.

The analysis presented above supports the monophyly of Pararhinebothroides and Rhinebothroides, but indicates that Anthocephalum as conceived by Ruhnke (1994) is a paraphyletic assemblage, regardless of the inclusion or exclusion of the so-called "covert members" of the genus (placed at the base of the tree in Fig. 4 with a dotted line indicating our lack of knowledge about their precise placement). Had Ruhnke (1994) included the existing database provided by Brooks, Thorson, and Mayes (1981) (also Brooks and Amato, 1992; Brooks and McLennan, 1993), and used some form of phylogenetic analysis, perhaps his analysis would not have been so flawed. His study provides a graphic illustration that phenetic homogeneity does not mean phylogenetic relatedness. This is particularly important when attempting to evaluate the phylogenetic generality of variation in microtriche features; at no point did Ruhnke (1994) discuss, or even acknowledge, published data indicating that at least some presumptive microtriche synapomorphies are plesiomorphic at very general levels (see Hoberg et al., 1995; Hoberg et al., 1997). We also note that in describing Anthocephalum alicae, Ruhnke (1994) failed to compare the species with Phyllobothrium kingae Schmidt, 1978, which he nonetheless included as a "covert member" of Anthocephalum. Based on examination of the type specimens of $P$. kingae (USNMPC 74636, 74637) by D.R.B., it seems possible that $A$. alicae is a junior synonym of $P$. kingae. The only feature by which they can be distinguished is number of testes per proglottid, 26-32 in P. kingae versus 31-45 in A. alicae. Before synonimizing the 2 species, however, $P$. kingae needs to be redescribed.

\section{DISCUSSION}

Finding the sister species of Rhinebothroides inhabiting an inshore marine stingray living along the Pacific coast of South America corroborates the hypothesis, first proposed by Brooks, Thorson, and Mayes (1981) and supported by a number of additional studies (see Brooks and McLennan [1993] for a summary; also Hoberg et al., 1998), that the common ancestor of 
TABLE I. Data matrix summarizing character argumentation for 9 transformation series for 7 species of Rhinebothroides.*

\begin{tabular}{lc}
\hline & Character \\
\cline { 2 - 2 } Species & 123456789 \\
\hline OG & 000000000 \\
MO & 110100211 \\
VE & 110101211 \\
CI & 110100322 \\
SC & 110001322 \\
FR & 111000200 \\
GL & 111011000 \\
MC & 111011100 \\
\hline
\end{tabular}

$* \mathrm{OG}=$ outgroup $; \mathrm{MO}=R$. moralarai $; \mathrm{VE}=R$. venezuelae $; \mathrm{CI}=R$. circular isi $; \mathrm{SC}=R$. scorzai $; \mathrm{FR}=R$. freitasi $; \mathrm{GL}=R$. glandularis $; \mathrm{MC}=R$. mclennanae. $1,0=$ vas deferens not expanded to form an external seminal vesicle; 1 = vas deferens expanded close to insertion to form an external seminal vesicle; $2,0=$ aporal ovarian lobes not elongate; $1=$ aporal ovarian lobes elongate; $3,0=$ vitellaria interrupted near genital pore on poral side; 1 $=$ vitellaria not interrupted near genital pore on poral side; $4,0=$ poral ovarian lobe extending anterior to posterior end of cirrus sac; $1=$ poral ovarian lobe not extending anterior to posterior end of cirrus sac; $5,0=$ no darkly staining glandular cells lying free in parenchyma surrounding the terminal genitalia; $1=$ darkly staining glandular cells lying free in parenchyma surrounding the terminal genitalia; $6,0=$ proglottids acraspedote $1=$ proglottids craspedote; 7, $0=$ average of $39-45$ testes per proglottid; $1=$ average of 31 testes per proglottid; $2=$ average of 53-55 testes per proglottid; $3=$ average of 77-80 testes per proglottid; $8,0=69-79$ loculi per bothridiaum; $1=49-59$ loculi per bothridiaum; $2=41-45$ loculi per bothridiaum; $9,0=$ maximum length of cirrus sacs $300-400 \mu \mathrm{m} ; 1=$ maximum length of cirrus sacs less than $200 \mu \mathrm{m} ; 2$ = maximum lengths of cirrus sacs greater than 500 $\mu \mathrm{m}$.

the freshwater stingrays originated in the Pacific Ocean, entering freshwater before the uplifting of the Andes. In addition, the discovery of the sister species of Rhinebothroides permits us to reassess the phylogenetic hypothesis for the 7 known species of Rhinebothroides (Brooks and Amato, 1992; see also Brooks and McLennan [1993]).

The current phylogenetic hypothesis for Rhinebothroides is based on 9 transformation series drawn from comparative morphologic study proposed by Brooks and Amato (1992). Reexamination of the polarization of character states within those transformation series using Pararhinebothroides hobergi as the primary outgroup (Maddison et al., 1984; Brooks and McLennan, 1991; Wiley et al., 1991), supports the existing polarization decisions for transformation series 1-2, 4, 6-7, and 9 of Brooks and Amato (1992), and suggests changes in 3 others. Transformation series 3 pertained to the vitellaria arround the genital pore. Interrupted vitellaria were originally coded as apomorphic within Rhinebothroides, but given the widespread occurrence of this condition among the species discussed above, we have reversed the coding of this character. Transformation series 5 was the nature of the vagina. The vaginae in Anthocephalum cairae, A. centrurum, A. alicae, and Pararhinebothroides hobergi are coiled, as are those of Rhinebothroides scor$z a i, R$. freitasi, $R$. glandularis, and $R$. mclennanae. Reexamination of type specimens of $R$. moralarai, $R$. venezuelae, and $R$. circularisi confirmed that they also have coiled vaginae. Brooks and Amato (1992) had considered a coiled vagina plesiomorphic for Rhinebothroides; we consider this trait now to be an additional synapomorphy for the clade including Anthocephalum cairae, A. centrurum, A. alicae, Pararhinebothroides, and Rhinebothroides (character 6 on the tree in Fig. 4). This

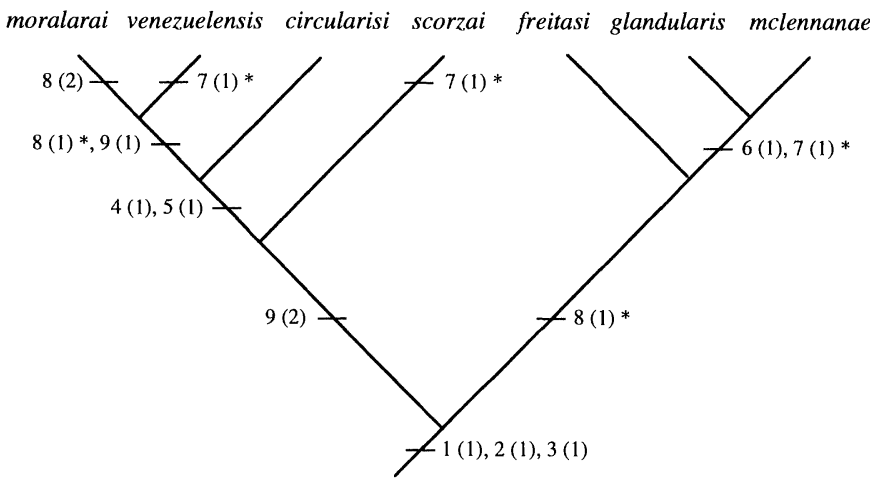

FIGURE 5. Phylogenetic tree for Rhinebothroides spp. Numbers accompanying slash marks on various branches represent the characters and their states as given in Table I.

character is thus eliminated from analysis of Rhinebothroides spp. Finally, transformation series 8 was the average number of testes per proglottid. Pararhinebothroides hobergi has an average of 39 testes per proglottid. This suggests that the large number of testes (an average of 80 and 77, respectively) exhibited by Rhinebothroides scorzai and $R$. circularisi is apomorphic, even though functional outgroup analysis (see Brooks and Amato, 1992) had suggested the opposite.

In this study we include a new transformation series, maximum cirrus sac length. Pararhinebothroides hobergi has cirrus sacs up to $300 \mu \mathrm{m}$ long, similar to those found in Rhinebothroides freitasi (up to $390 \mu \mathrm{m}$ long), $R$. glandularis (up to 408 $\mu \mathrm{m}$ long), and $R$. mclennanae (up to $344 \mu \mathrm{m}$ long). Rhinebothroides venezuelae and $R$. moralarai have cirrus sacs less than $200 \mu \mathrm{m}$ long, whereas $R$. scorzai and $R$. circularisi have cirrus sacs more than $500 \mu \mathrm{m}$ long. Anthocephalum centrurum, A. alicae, and Phyllobothrium kingae have maximum cirrus sac lengths of 259-269 $\mu \mathrm{m}$. Using $P$. hobergi as the primary outgroup (Maddison et al, 1984; Brooks and McLennan, 1991; Wiley et al., 1991), the conditions found in Rhinebothroides venezuelae and $R$. moralarai, and in $R$. scorzai and $R$. circularisi are considered apomorphic. We use maximum rather than mean cirrus sac length because the cirrus sac length changes during the ontogeny of each proglottid. Mean values are appropriate and often useful for characters such as number of marginal loculi per bothridium or number of testes per proglottid, which are not affected by development.

When the 9 transformation series are analyzed phylogenetically (Table I is the data matrix), a single most parsimonious phylogenetic tree is obtained (Fig. 5), with a consistency index of $81.3 \%$, retention index of $82.4 \%$, and rescaled consistency index of $66.9 \%$. The topology of the new tree differs from that depicted by Brooks and Amato (1992) only in the placement of $R$. scorzai, which was previously considered the sister species of $R$. freitasi $+R$. glandularis $+R$. mclennanae.

\section{ACKNOWLEDGMENTS}

We gratefully acknowledge the cooperation and assistance of Ing. Alfonso Espinosa Ramo, Rector of the Escuela Politecnica Nacional, as well as officials of the Ministry of Defense and the Ministry of Agriculture, Republic of Ecuador, both in Quito and in various localities in the province of El Oro. We thank 
the people of Puerto Hualtaco and of Puerto Jelí, in particular, for their unparalleled hospitality during our study. This study was funded through operating grant A7696 from the Natural Sciences and Engineering Research Council (NSERC) of Canada.

\section{LITERATURE CITED}

Brooks, D. R., ANd J. F. R. Amato. 1992. Cestode parasites in Potamotrygon motoro (Muller and Henle) (Chondrichthyes: Potamotrygonidae) from southwestern Brazil, including Rhinebothroides mclennanae sp. n. (Tetraphyllidea: Phyllobothriidae) and a reviser host-parasite checklist for helminths inhabiting Neotropical freshwater stingrays. Journal of Parasitology 78: 393-398.

Brooks, D. R., AND R. BARRIGA. 1995. Serendip deborahae n. gen. et. n. sp. (Eucestoda: Tetraphyllidea: Serendipidae fam. nov.) in Rhinobatos steindachneri Evermann and Jenkins, 1891 (Chondrichthyeses: Myliobatiformes: Myliobatidae) from southeastern Ecuador. Journal of Parasitology 81: 80-84.

Brooks, D. R., M. A. MAYes, and T. B. ThORSON. 1981a. Systematic review of cestodes infecting freshwater stingrays (Chondrichthyes: Potamotrygonidae) including four new species from Venezueli Proceedings of the Helminthological Society of Washington 48: 43-64.

goodei Garman (Myliobatiformes: Myliobatidae) from Rio de la Plata, Uruguay with a summary of cestodes collected from South American elasmobranchs during 1975-79. Proceedings of the Biological Society of Washington 93: 1239-1252.

- - AND D. A. MCLENNAN. 1991. Phylogeny, ecology and behavior: A research program in comparative biology. University of Chicago Press, Chicago, Illinois, $434 \mathrm{p}$.

, AND - 1993. Parascript: Parasites and the language of evolution. Smithsonian Institution Press, Washington, D.C., 429 p. - T. B. ThORSON, AND M. A. MAYEs. 1981. Freshwater stingrays (Potamotrygonidae) and their helminth parasites: Testing hypotheses of evolution and coevolution. In Advances in cladistics: Proceedings of the first meeting of the Willi Hennig society, V. A Funk and D. R. Brooks (eds.). New York Botanical Garden, New York, New York, p. 147-175.

CAmpbell, R. A., AND A. D. Williams. 1984. Tylocephalum Linton, 1890 (Cestoda: Lecanicephalidea) from the cownose ray, Rhinoptera bonasus (Mitchill, 1815) with a discussion of its validity and systematic relationships. Proceedings of the Helminthological Society of Washington 51: 121-134.

HoberG, E. P., A. M. Adams, AND R. L. RausCH. 1991. Revision of the genus Anophryocephalus Baylis, 1922 from pinnipeds in the Holarctic, with descriptions of Anophryocephalus nunivakensis sp. nov., and A. eumetopii sp. nov. (Tetrabothriidae) and evaluation of records from the Phocidae. Canadian Journal of Zoology 69: 16531668.

- D. R. Brooks, H. Molina-Ureña, and E. Erbe. 1998. Echinocephalus janzeni $\mathrm{n}$. sp. (Nematoda: Gnathostomidae) in Himatura pacifica (Chondrichthyes: Myliobatiformes) from the Pacific coast of Costa Rica and Mexico, with historical biogeographic analysis of the genus. Journal of Parasitology 84: 571-581.

, J. Mariaux, J.-L. Justine, D. R. Brooks, and P. J. Weekes. 1997. Phylogeny of the orders of the Eucestoda (Cercomeromorphae) based on comparative morphology: Historical perspectives and a new working hypothesis. Journal of Parasitology 83: 112147.

- AND L. N. MEASURES. 1995. Anophryocephalus inuitorum sp. nov. and $A$. arcticensis sp. nov. (Eucestoda: Tetrabothriidae) in ringed seals (Phoca hispida hispida) and harp seals (Phoca groenlandica) from high-latitude seas of eastern Canada and the Arctic basin. Canadian Journal of Zoology 73: 34-44.

$\longrightarrow$, D. E. SIMS, AND P. H. ODENSE. 1995. Comparative morphology of the scolices and microtriches among 5 species of Tetrabothrius (Eucestoda: Tetrabothriidae). Journal of Parasitology 81: 475-481.

Maddison, W. P., M. J. Donoghue, and D. R. Maddison. 1984. Outgroup analysis and parsimony. Systematic Zoology 33: 83-103.

Mayes, M. A., D. R. Brooks, AND T. B. Thorson. 1981. Two new tetraphyllidean cestodes from the freshwater stingray Potamotrygon circularis (Garman), with proposal of a new genus. Proceedings of the Helminthological Society of Washington 48: 38-42.

RuHNKE, T. R. 1994. Resurrection of Anthocephalum Linton, 1890 (Cestoda: Tetraphyllidea) and taxonomic information on five proposed members. Systematic Parasitology 29: 159-176.

SwOFFORD, D. L. 1993. PAUP: Phylogenetic analysis using parsimony, version 3.1.1. Illinois Natural History Survey, Champaign, Illinois.

Toth, L. M., R. A. Campbell, and G. D. Schmidt. 1992. A revision of Oncomegas Dollfus, 1929 (Cestoda: Trypanorhyncha: Eutetrarhynchidae), the description of two new species and comments on its classification. Systematic Parasitology 22: 167-187.

Wiley, E. O., D. Siegel-Causey, D. R. Brooks, and V. A. Funk. 1991. The compleat cladist: A primer of phylogenetic procedures. University of Kansas Museum of Natural History Press, Lawrence, Kansas. 158 p. 